\title{
Aspects of the Physico-Chemical Characteristics of Rivers in Kahuzi-Biega National Park, Democratic Republic of Congo
}

\author{
Mashimango Bagalwa ${ }^{1,2}$, Niganda Zirirane ${ }^{1,2}$, Stephen Pauls ${ }^{3}$, Katcho Karume ${ }^{2,4}$, Mwangi Ngera ${ }^{1}$, \\ Mubwebwe Bisimwa $^{1}$, Natchigera Gustave Mushagalusa ${ }^{2}$ \\ ${ }^{1}$ Department of Biology, Centre de Recherche en Sciences Naturelles, Bukavu, Democratic Republic of Congo; ${ }^{2}$ Université \\ Evangélique en Afrique, Faculté d'Agronomie et Environnement, Bukavu, Democratic Republic of Congo; ${ }^{3}$ University of Minnesota, \\ Department of Entomology, St. Paul, USA; ${ }^{4}$ Geochemistry and Environment Department, Goma Volcano Observatory, Bukavu, \\ Democratic Republic of Congo. \\ Email: mashibagalwa@yahoo.fr
}

Received September $4^{\text {th }}, 2012$; revised October $1^{\text {st }}, 2012$; accepted November $2^{\text {nd }}, 2012$

\begin{abstract}
The physico-chemical characteristics of ten permanently flowing rivers from Kahuzi Biega National Park (Democratic Republic of Congo) were examined in July 2007. Water samples were collected from ten sites between 1800 and 3200 $\mathrm{m}$ asl and analyzed for the following chemical parameters: biological oxygen demand, total and carbonate hardness, alkalinity, total phosphorus, nitrogen, nitrate, and ammonia. Discharge, current velocity, temperature, and oxygen saturation were analyzed on site. In general, the chemical parameters revealed relatively low concentrations compared to others rivers in the region. The rivers were cold $\left(10^{\circ} \mathrm{C}-15^{\circ} \mathrm{C}\right.$ ), well oxygenated, had low conductivity (generally $<100$ $\mu \mathrm{S} / \mathrm{cm})$, and had $\mathrm{pH}$ values ranging between 5.5 and 7.6. Nitrogen and phosphorus were also low $(0.086-0.25 \mu \mathrm{mol} / \mathrm{L}$ for phosphorus and $2.21-4.25 \mu \mathrm{mol} / \mathrm{L}$ for nitrogen) in all rivers. The main natural sources of nitrogen and other nutriaents are from rain and atmospheric deposition, organic matter decomposition, and fixation of molecular nitrogen from allochthonous inorganic material. In the forested rivers of Kahuzi-Biega National Park the terrestrial and riparian environments are the only sources of nitrogen and phosphorus to the river water.
\end{abstract}

Keywords: Physico-Chemical; Parameters; Rivers; Kahuzi-Biega National Park

\section{Introduction}

While colonial hydrobiological expeditions made important contributions to providing general synthesis of the tropical freshwater communities in the eastern DR Congo [1-3], no basic analyses of the running waters within Kahuzi-Biega National Park have been reported to date. Presently, the knowledge of the ecology of the park's rivers and swamps is generally poor, though the park protects some of the last undisturbed water courses and swamps in the otherwise very densely populated region.

In any natural ecosystem, many variables change with time and location with little opportunity to control them all systematically or otherwise [4]. The most important anthropogenic factor influencing the aquatic ecosystems of the eastern DR Congo has been the change in land use [5-7], which has seen most unprotected lands converted from natural forest vegetation to intensively used systems either for resource exploitation, for agricultural use, or living space [5]. Many of the aquatic ecosystems of the Albertine Rift Valley have been found to be particularly diverse. The most famous examples include Lakes Kivu and Tanganyika, with unique and many endemic species [8-12], and the Kalengo River [13]. However biological and physico-chemical information on the Albertine Rift Valley Rivers remains scarce.

The fauna of several small, permanent, high altitude rivers in Kahuzi-Biega National Park has been studied [14]. While these rivers are characterised by higher flow during the rainy season, an understanding of the physico-chemical characteristics would help explain the altitudinal distribution of macro-invertebrate, fish and others aquatic animals. Some species or even larger taxonomic groups of animals are particular attached to particular habitats. The bottom of mountain streams and rivers composed of mud and aquatic animals are differently distributed in this ecosystem [15]. Few studies have been carried out on Kahuzi-Biega National Park Rivers. The current study intends to provide reasons for the altitude- 
inal distribution of certain species. Meteorological data from the Centre de Recherche en Sciences Naturelles Lwiro, located $4 \mathrm{~km}$ from the closest study site at $1740 \mathrm{~m}$ asl, shows that mean annual rainfall is $1500 \mathrm{~mm} /$ year with a clear dry season (June, July and August) in the region. The mean monthly temperature is $19.7^{\circ} \mathrm{C}$ (Mankoto, 1994; Bagalwa 2006).

The catchment characteristics are the primary factors shaping the natural chemical composition of the water. As water flows downstream within a catchment, it dissolves and carries varying amounts of mineral, organic and gaseous compounds, depending on the type of rock or soil it flows through. The chemical composition of stream water is changed radically when the catchment changes from forested to deforested or over-crowded areas [16]. The chemical composition of the surface waters is also subject to the influence of the settling organisms since in these waters the two basic processes of photosynthesis and respiration take place continuously. In the course of the last several decades the waters have been rapidly enriched with compounds participating in photosynthesis, nitrogen and phosphorus and as a result the balance between photosynthesis and respiration has been disturbed [17]. This in turn leads to the accumulation of organic matter in the water and deep changes in its chemical properties often resulting in the degradation of the water. Limnological studies in the region are inexistent except the works of Kimbadi et al. [18] and Dubois [19] concerning the small rivers of the north western part of Lake Tanganyika and Bagalwa $[7,20]$ in rivers tributaries of Lake Kivu. No studies have been reported done in the Kahuzi Biega National Park Rivers as natural ecosystem.

This work aims to trace the changes in the chemical composition of the affluent in 10 Kahuzi-Biega National Park Rivers and to determine the habitat preferences of macro-invertebrates fauna occurring in a stream in this protected area. The investigation of water quality can help in estimating the current condition and the stress on biodiversity in the Kahuzi-Biega National Park Rivers.

\section{Material and Methods}

\subsection{Study Area}

Kahuzi-Biega National Park is located west of Lake Kivu and covers an area of $6000 \mathrm{Km}^{2}$ between 600 and 3308 $\mathrm{m}$ altitude (Figure 1).

The Park comprises a highland region $\left(600 \mathrm{Km}^{2}\right)$ and a lowland region $\left(5.4 \mathrm{~km}^{2}\right)$, which are connected by a forest corridor. Forty-four species of larger mammals (including ten primate species) have been reported from the highland region, fifty-six species (fourteen primate species) from the lowland region [21].

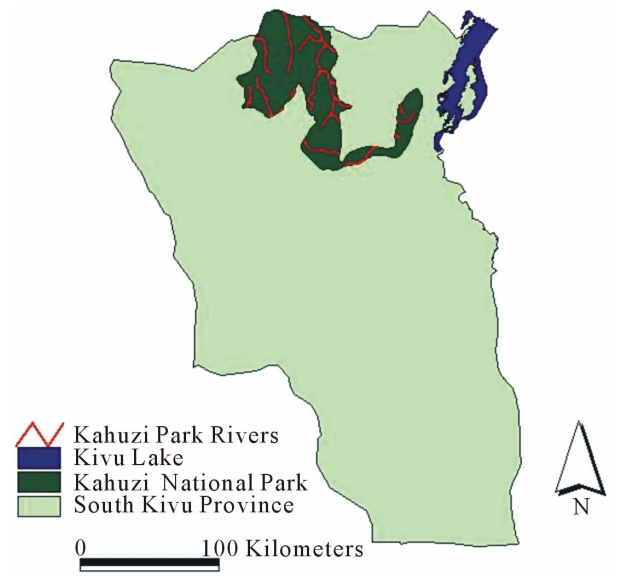

Figure 1. Kahuzi national park and hydrology.

The highland region is characterised by bamboo forest (Arudinaria alpine) (37\%), primary mountain forest $(28 \%)$ in the west and northern parts of the Park, seconddary mountain forest $(20 \%)$ in the eastern part, Cyperus latifolius swamp (7\%) and vegetation (8\%), as described by Goodall [22] and Murnyak [23].

The localization of ten rivers flowing in the highland region in the Chivanga sector of Kahuzi-Biega National Park is presented in Figure 2.

\subsection{Sampling and Analysis of Water}

Forty-eight water samples were taken from 10 small rivers in the Kahuzi Biega National Park from 15-30 July, 2007, following the methodology of Golterman et al., [24] and Wetzel and Likens [25]. Water for the chemical analysis was collected in pre-washed plastic containers. Temperature, Dissolved oxygen (DO), $\mathrm{pH}$, and conductivity were determined immediately after sampling in situ using a pre-calibrated portable $\mathrm{pH}-\mathrm{Oxygen}$ meter (Horiba Ltd. Kyoto, Japan). Chemical Oxygen Demand (DCO) and Biochemical Oxygen Demand (BOD) were determined through the iodometry method [26]. Suspended Solid (SS) was defined as the material retained by a $0.45-\mu \mathrm{m}$ filter and discharge were estimate using Rating curve method $[27,28]$. From the filtered fraction, phosphate, silicate, nitrite, nitrate, and ammonium were determined through colorimetric methods [25]. Concentrations found for the parameters studied at the different sampling stations were compared through analysis of variance (one-way ANOVA) with a 95\% significance level.

\section{Results and Discussion}

Most of the rivers were slightly acid (Table 1) except the Mushova and Mugaba rivers whose $\mathrm{pH}$ was 7.6 and 7.1 respectively. Water temperature was lower in rivers with 


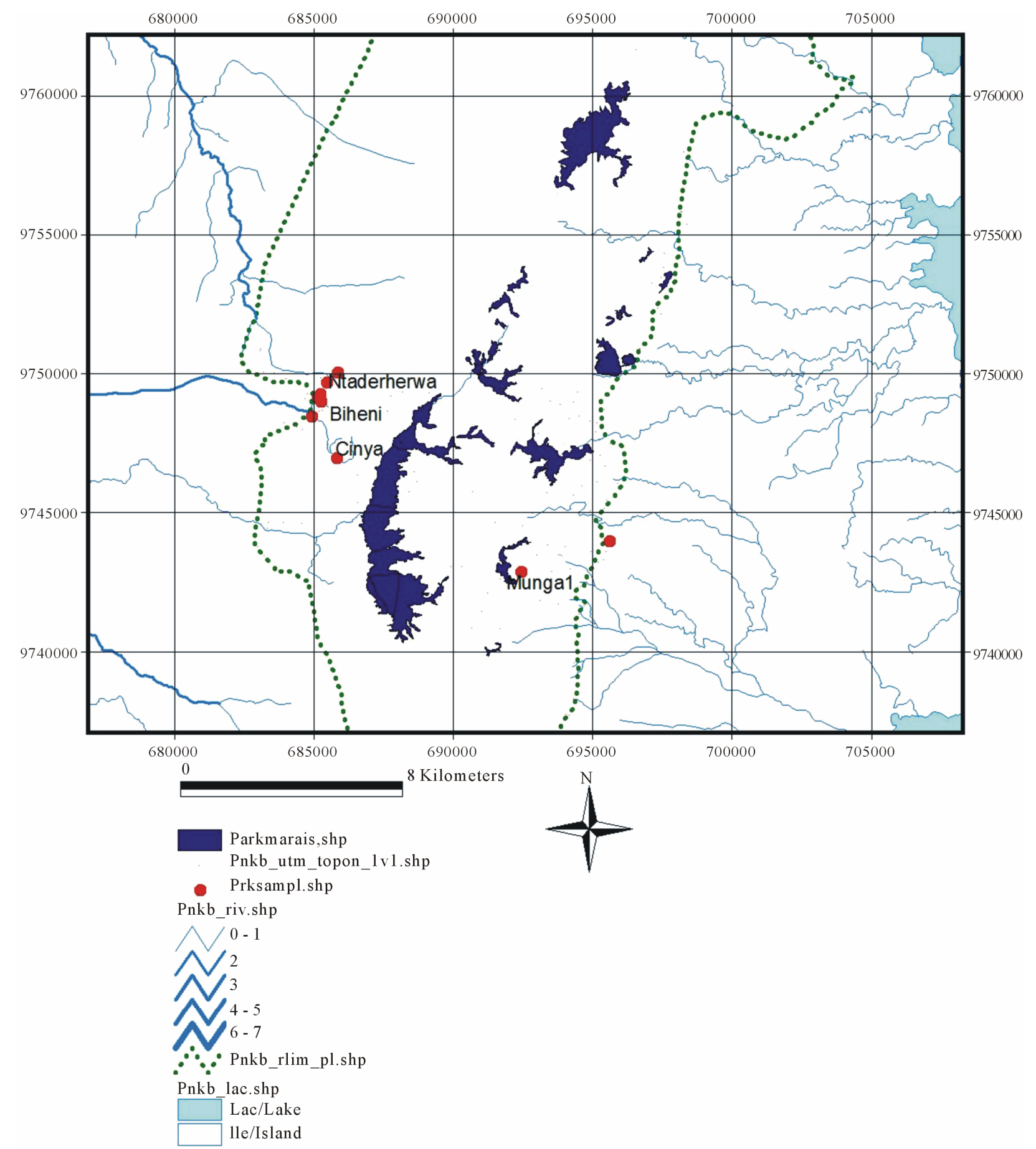

Figure 2. Localisation of sampling sites.

sources at higher altitudes. These lower temperatures are primarily the result of the high altitude of the springs and greater shading effects of denser riparian cover. The surface water here is cooler $\left(11^{\circ} \mathrm{C}-15^{\circ} \mathrm{C}\right)$ than in many others African rivers $\left(19^{\circ} \mathrm{C}-28^{\circ} \mathrm{C}\right)$ at similar altitudes in Malawi, Burundi, Morocco, Nigeria and Zibambwe [4, 18,19,29-32]. The Odzi River in Zimabwe flows at the same altitude $(2200 \mathrm{~m})$, but has higher temperature regime $\left(19.3^{\circ} \mathrm{C}-28.0^{\circ} \mathrm{C}\right)$ [4]. Many other rivers in the region close to Kahuzi-Biega National Park have higher water temperature $[7,20]$, particularly where riparian vegetation has been cleared or anthropogenic activities abound.

Most of the rivers were not saturated with oxygen. The 
Table 1. Physico-chemical parameters of Kahuzi-Biega National Park Rivers.

\begin{tabular}{|c|c|c|c|c|c|c|c|c|c|c|}
\hline Parameters/Rivers & Chande & Mushuva & Bwangizi & Mirembo & Lwanga & Mugaba & Chitori & Chumba & Cinhya & Nabugobugo \\
\hline Temperature $\left({ }^{\circ} \mathrm{C}\right)$ & $14.1 \pm 0.2$ & $11.25 \pm 1.34$ & $13.8 \pm 0.2$ & $13.3 \pm 0.3$ & $14.9 \pm 0.12$ & & & & $13.3 \pm 0.01$ & $13.8 \pm 0.12$ \\
\hline $\begin{array}{l}\text { Dissolved } \\
\text { Oxygen }(\mathrm{mg} / \mathrm{L})\end{array}$ & $7.6 \pm 0.301$ & $6.2 \pm 0.71$ & $5.68 \pm 0.58$ & $6.1 \pm 0.42$ & $7.55 \pm 0.2$ & $4.8 \pm 2.1$ & $5.38 \pm 0.3$ & $5.7 \pm 0.4$ & $2.6 \pm 0.2$ & $4.3 \pm 0.2$ \\
\hline $\begin{array}{l}\text { Saturation in } \\
\text { Oxygen }(\%)\end{array}$ & $65 \pm 0.4$ & $65 \pm 0.23$ & $55 \pm 0.23$ & $59.5 \pm 2.8$ & $74 \pm 0.01$ & $47.4 \pm 3.4$ & $53 \pm 1.2$ & $56.8 \pm 0.8$ & $25.5 \pm 0.01$ & $41.85 \pm 0.07$ \\
\hline $\mathrm{pH}$ & $6.14 \pm 0.4$ & $7.66 \pm 0.11$ & $6.13 \pm 0.45$ & $6.3 \pm 0.2$ & $6.98 \pm 0.1$ & $7.1 \pm 0.4$ & $5.51 \pm 1.1$ & $5.6 \pm 0.8$ & $5.7 \pm 0.4$ & $5.6 \pm 0.4$ \\
\hline Conductibility $(\mu \mathrm{S})$ & $54 \pm 4.2$ & $64 \pm 3.0$ & $13 \pm 2.5$ & $17 \pm 2.0$ & $17 \pm 3.2$ & $23.6 \pm 0.34$ & $14 \pm 2.4$ & & $11.5 \pm 0.8$ & $12.5 \pm 1.2$ \\
\hline Total hardness $\left({ }^{\circ} \mathrm{F}\right)$ & $25.06 \pm 0.82$ & $26.49 \pm 1.12$ & $28.82 \pm 0.22$ & $30.1 \pm 1.2$ & $45.1 \pm 0.01$ & $47.1 \pm 2.3$ & $16.02 \pm 3.2$ & $25.3 \pm 0.1$ & $14.7 \pm 1.2$ & $31.6 \pm 0.02$ \\
\hline Calcic hardness $\left({ }^{\circ} \mathrm{F}\right)$ & $8.05 \pm 0.2$ & $6.9 \pm 2.3$ & $3.76 \pm 0.89$ & $4 \pm 0.48$ & $6.27 \pm 0.04$ & $5.9 \pm 1.01$ & $2.23 \pm 1.12$ & $1.59 \pm 1.04$ & $1.52 \pm 1.1$ & $4.03 \pm 0.06$ \\
\hline Alkalinity (mg/L) & $14 \pm 0.03$ & $13 \pm 0.1$ & $6 \pm 1.2$ & $5.5 \pm 0.5$ & $11 \pm 0.06$ & $6.3 \pm 0.7$ & $2 \pm 0.8$ & $2 \pm 0.4$ & $2.5 \pm 0.5$ & $3.5 \pm 0.02$ \\
\hline $\begin{array}{l}\text { Biological Oxygen } \\
\text { Demand }-5(\mathrm{mg} / \mathrm{L})\end{array}$ & $4.3 \pm 0.4$ & $3.83 \pm 0.23$ & $1.66 \pm 1.4$ & $3.99 \pm 0.2$ & $4.05 \pm 0.23$ & $5 \pm 0.5$ & $3.27 \pm 0.3$ & $2.91 \pm 2.5$ & $4.84 \pm 0.4$ & $4.88 \pm 0.6$ \\
\hline $\begin{array}{l}\text { Suspended } \\
\text { solid (mg/L) }\end{array}$ & $0.96 \pm 0.12$ & $1.46 \pm 0.34$ & $0.78 \pm 0.13$ & $0.85 \pm 0.14$ & $0.12 \pm 0.4$ & $0.2 \pm 0.05$ & $0.29 \pm 0.01$ & $0.09 \pm 0.1$ & $0.082 \pm 0.03$ & $0.18 \pm 0.07$ \\
\hline Charge $\left(\mathrm{m}^{3} / \mathrm{S}\right)$ & $0.015 \pm 0.1$ & $0.1 \pm 0.42$ & $0.747 \pm 0.04$ & $0.03 \pm 0.01$ & $0.088 \pm 0.02$ & $0.11 \pm 0.04$ & $0.021 \pm 0.09$ & $0.058 \pm 0.07$ & $0.036 \pm 0.01$ & $0.074 \pm 0.04$ \\
\hline Speed $(\mathrm{m} / \mathrm{S})$ & $0.08 \pm 0.03$ & $0.20 \pm 0.05$ & $0.51 \pm 0.01$ & $0.22 \pm 0.13$ & $0.42 \pm 0.02$ & $0.36 \pm 0.02$ & $0.31 \pm 0.02$ & $0.36 \pm 0.01$ & $0.25 \pm 0.02$ & $0.36 \pm 0.04$ \\
\hline $\begin{array}{l}\text { Total Phosphorus } \\
(\mu \mathrm{mol} / \mathrm{L})\end{array}$ & $0.55 \pm 0.04$ & $0.29 \pm 0.02$ & $0.086 \pm 0.01$ & $0.09 \pm 0.01$ & $0.11 \pm 0.01$ & $0.17 \pm 0.01$ & $0.11 \pm 0.01$ & $0.12 \pm 0.01$ & $0.25 \pm 0.02$ & $0.13 \pm 0.11$ \\
\hline $\begin{array}{l}\text { Total Nitrogen } \\
(\mu \mathrm{mol} / \mathrm{L})\end{array}$ & $4.25 \pm 1.1$ & $2.84 \pm 1.03$ & $2.79 \pm 0.03$ & $3.65 \pm 1.02$ & $3.4 \pm 0.06$ & $3.51 \pm 0.06$ & $3.57 \pm 0.04$ & $2.21 \pm 0.8$ & $3.65 \pm 0.07$ & $3.57 \pm 0.01$ \\
\hline Nitrite $(\mu \mathrm{mol} / \mathrm{L})$ & $0.52 \pm 0.02$ & $0.38 \pm 0.1$ & $0.75 \pm 0.023$ & $0.28 \pm 0.06$ & $0.26 \pm 0.04$ & $0.38 \pm 0.04$ & $0.5 \pm 0.05$ & $0.53 \pm 0.03$ & $0.45 \pm 0.04$ & $0.50 \pm 0.01$ \\
\hline Nitrate $(\mu \mathrm{mol} / \mathrm{L})$ & $0.35 \pm 0.08$ & $0.32 \pm 0.2$ & $0.31 \pm 0.08$ & $0.31 \pm 0.06$ & $0.22 \pm 0.3$ & $0.28 \pm 0.03$ & $0.25 \pm 0.1$ & $0.28 \pm 0.02$ & $0.35 \pm 0.01$ & $0.25 \pm 0.05$ \\
\hline Ammonia $(\mu \mathrm{mol} / \mathrm{L})$ & $3.38 \pm 1.23$ & $2.42 \pm 0.17$ & $1.73 \pm 1.1$ & $3.06 \pm 0.12$ & $2.92 \pm 1.2$ & $2.84 \pm 0.03$ & $2.82 \pm 0.1$ & $1.4 \pm 0.01$ & $1.38 \pm 0.02$ & $2.8 \pm 0.05$ \\
\hline
\end{tabular}

highest values of saturation were recorded in Langa (74\%), the lowest values in Cinya $(25.5 \%)$. The low oxygen saturation levels may be attributed to the decomposition of organic matter and vegetation decay. This was also observed in other rivers in India [33]. The effect of vegetation on rivers is largely determined by the oxygen balance of the system and its presence is essential to maintain biological life within a system [34]. It is admitted that self depuration potential of a stream is exceeded when oxygen saturation sinks under $50 \%$.

The alkalinity of the water sample varied between 2 and $14 \mathrm{meq} / \mathrm{L}$. This reflects the alkaline soils and underlying alkaline igneous geology of Kahuzi-Biega National Park. In these rivers alkalinity was high comparatively to other African rivers $(2.5 \mathrm{meq} / \mathrm{L})$. These high values are due to the variability of soils and the geology in this volcanic region. Soils contain limestone minerals such as calcite and dolomite and therefore alkalinity in the rivers is higher compared to other African rivers [35,36].

$\mathrm{BOD}_{5}$ values indicate the extent of respiratory activity in the aquatic systems. High levels of $\mathrm{BOD}_{5}$ indicate organic pollution, which adversely affect the water qual- ity. In all samples, $\mathrm{BOD}_{5}$ values were low and less than 5 $\mathrm{mg} / \mathrm{L}$. River Chumba, had very low $\mathrm{BOD}_{5}(2.91 \mathrm{mg} / \mathrm{L})$. Relatively high values were observed in River Mugaba $(5 \mathrm{mg} / \mathrm{L})$ which are likely linked to naturally high organic matter levels in the river. This river flow through a swamp and animals such as elephants used this river for drinking and washing.

Total suspended solids in all the rivers ranged greatly from about 80 to $1460 \mathrm{mg} / \mathrm{L}$. The highest values were observed in river Mushuva. This river is used for gold and Colombo-tantalite mining operations. The increased erosion and surface runoff is probably the reason for the high values observed. Compared to other rivers in tropical region, the values recorded in Kahuzi-Biega Rivers are intermediate. In the Odzi river total suspended solids range between $40 \mathrm{mg} / \mathrm{l}$ to $107 \mathrm{mg} / \mathrm{l}$ [4] and in Shanmuganadha river in India it is high $2310 \mathrm{mg} / 1$ [33]. The difference is significant between the different chemical parameter using ANOVA between rivers $(\mathrm{p}<0.05)$. Agricultural development and deforestation may alter the suspended solid load by increasing erosion and altering local sediment budgets [32]. This is not yet the case for 
Kahuzi-Biega National Park Rivers. The low suspended solids concentration observed in the study sites reflects the filtering capacity of intact forest ecosystems within the river catchments.

Phosphates and nitrates are important parameters to assess water quality, as they often are limiting nutrients and high concentrations indicate nutrient enrichment and eutrophication [27,32]. Photosynthesis and respiration play an important role in the self purification of natural water [15]. The disturbance of the stationary state between photosynthesis and respiration leads to chemical and biological changes reflecting pollution. Total phosphorus varied between 0.086 and $0.55 \mu \mathrm{mol} / 1$ and total dissolved inorganic nitrogen between 2.21 and 4.25 $\mu \mathrm{mol} / \mathrm{l}$. High levels of these species increase the growth of vegetation in water systems and increase the oxygen demand. Concentration of total phosphate in KahuziBiega National Park rivers are generally low than concentration found in other rivers in the region [20]. The low concentration of phosphorus can be attributed to anthropogenic effect inexistent in these rivers and the low temperature. The high temperatures allow the mineralization of organic matter in the bottom by bacteria and microzooplankton [37]. No much nitrate was found in the Water Rivers and virtually the same concentration in all rivers. It was found that where the riparian zone has been cut, the stream side buffering capacity is reduced and higher levels as dissolved nitrogen will enter the stream via ground water base flow [38]. But in Kahuzi-Biega National Park Rivers the vegetation is not cut off then the buffering capacity increases, the rivers receive low concentration of nutrient.

Nutrient concentrations reported by the present study are lower than the levels described for other unpolluted rivers [36]. According to Golterman [39] the main sources of nitrogen to the aquatic environment are of anthropogenic origin, i.e. agricultural activities, human waste, and detergents. In Kahuzi-Biega National Park these sources do not exist for the majority of rivers flowing in. The main natural sources of nitrogen and other nutrients are from rain and atmospheric deposition, organic matter decomposition, and fixation of molecular nitrogen from allochthonous inorganic material [39]. In the forested rivers of Kahuzi-Biega National Park the terrestrial and riparian environments are the only sources of nitrogen and phosphorus to the river water.

\section{Conclusion}

In general, the chemical parameters revealed relatively low concentrations compared to others rivers in the region. The rivers were cold, well oxygenated, had low conductivity, and had $\mathrm{pH}$ values ranging between 5.5 and 7.6. Nitrogen and phosphorus were also in all rivers compared to other African rivers flowing at the same altitude. The main natural sources of nitrogen and other nutrients are from rain and atmospheric deposition, organic matter decomposition, and fixation of molecular nitrogen from allochthonous inorganic material.

\section{Acknowledgements}

The authors would like to thank ICCN (Institut Congolais pour la Conservation de la Nature) for granting permission to carry out research in the Kahuzi-Biega National Park. We also thank the staff of CRSN (Centre de Recherche en Sciences Naturelles de Lwiro) for laboratory work. We greatly appreciate the useful comments of Dr Bootsma and Dr Basabose on the manuscript. We are also greatly indebted to all guides, guards and field assistants at the Kahuzi-Biega National Park for their technical support and hospitality throughout the fieldwork. This study is part of the outcomes of the P-BEATRA programme of the Field Museum, Chicago, which was funded by the MacArthur Foundation.

\section{REFERENCES}

[1] G. Marlier, "Recherches Hydrobiologiques Dans les Rivières du Congo Orientale. Etude Ecologique," Hydrobiologia, Vol. 6, No. 3-4, 1952, pp. 225-263. doi:10.1007/BF00053675

[2] K. O. Viets and K. Bottger, "Zur Systematic und Okologie Rheophiler Hydrachnellae (Acari) Zentral Afrikas Teil 1," Acarologia, Vol. 16, No. 1, 1974, pp. 106159.

[3] K. Bottger, "Studies on the Productivity of Kalengo Stream in Central Africa," Archiv für Hydrobiologie, Vol. 75, No. 1, 1975, pp. 1-31.

[4] S. B. Jonnalagadda and G. Mhere, "Water Quality of the Odzi River in the Eastern High Lands of Zimbabwe," Water Resources, Vol. 35, No. 10, 2001, pp. 2371-2376.

[5] B. Caruso, "A Survey Comparing Streams from Forested and Deforested Watersheds to Assess Impact of Land Use Change on the Northeastern Shore of Lake Tanganyika," Nyanza Project Report, 2002, pp. 1-4.

[6] H. Eggermont and D. Verschuren, "Impact of Soil Erosion in Disturbed Tributary Drainages on the Benthic Invertebrate Fauna of Lake Tanganyika, East Africa," Biological Conservation, Vol. 113, No. 1, 2003, pp. 99-109. doi:10.1016/S0006-3207(02)00353-1

[7] M. Bagalwa, "The Impact of Land Use on Water Quality of the Lwiro River, Democratic Republic of Congo, Central Africa," African Journal of Aquatic Science, Vol. 31, No. 1, 2006, pp. 137-143.

[8] G. Fryer, and T. D. Iles, "The Cichlid Fishes of Great Lakes of Africa: Their Biology and Evolution," Olivier \& Boyd, Edinburgh, 1972, 641 p.

[9] D. F. E. Thys Van Audenaerde, E. Coenen, J. Robben and D. Vervoot, "Fishes Research on Lake Kivu," Royal Af- 
rica Museum, Tervuren, 1980.

[10] A. H. Kurt, and E. R. Hecky, "The Late Pleistocene and Holocene Stratigraphy and Paleolimnology of Lakes Kivu and Tanganyika," Palaeogeography, Palaeoclimatology, Palaeoecology, Vol. 61, 1987, pp. 169-197.

[11] G. W. Coulter, "Lake Tanganyika and Its Life," Oxford University Press, London, 1991.

[12] J. Snoeks, "De Haplochromis-Soorten (Teelostei, Cichlidae) van Het kivemeer: Een \& Taxonomic Revision", Doctoral Thesis, Tervuren, Belgium.

[13] J. P. Kopelke, "Ephemeroptera (Insecta) aus der Emergenz des Zentrafrikanischen Bergbaches Kalengo (Zaire). Teil II: Leptophebiidae, Heptageniidae, Tricorythidae, Caenidae," Bullettin de la Societe Entomologique Suise, Vol. 54, 1981, pp. 139-156.

[14] P. Steffen, B. Baluku, N. Mulimbwa, S. Amundala, M. Ngera, N. Byamunguand and M. Bisimwa, "Inventaire Systèmatique des Macroinvertébrés de Quelques Cours d'eau du Parc National de Kahuzi Biega (PNKB) et sa Région Adjacente," Programme-Biodiversité des Ecosystèmes Aquatiques et Terrestre du Rift Albertin, 2005, pp. 49-59.

[15] H. B. N. Hynes, "The Biology of Polluted Waters," Liverpool University Press, Liverpool, 1974.

[16] N. Raj and P. A. Azeez, "Spatial and Temporal Variation in Surface Water Chemistry of a Tropical River, the River Bharathapuzha, India," Current Science, Vol. 96, No. 2, 2009, pp. 245-241.

[17] M. Meybeck, "River Water Quality: Global Ranges, Time and Space Variabilities, Proposal for Some Redefinitions," Verhandlungen des Internationalen Verein Limnologie, Vol. 26, 1996, pp 81-96.

[18] S. Kimbadi, A. Vandelannoote, H. Deelstra, M. Mbemba M. and F. Ollevier, "Chemical Composition of the Small Rivers of the North-Western Part of Lake Tanganyika," Hydrobiologia, Vol. 407, 1999, pp. 75-80. doi:10.1023/A:1003749817147

[19] J. Dubois, "Evolution de la Température, de l'Oxygène Dissous et de la Transparence Dans la Baie Nord du Lac Tanganyika," Hydrobiologia, Vol. 10, No. 1, 1958, pp 215-240. doi:10.1007/BF00142188

[20] M. Bagalwa, "Environmental impact of Land Use Change on Water Quality of Inflowing Tributaries of Lake Kivu," Proceeding of 11th World Lakes Conference, Nairobi, 31 October-4 November 2005, pp. 379-383.

[21] M. Mankoto, J. Yamagiwa, B. Steinhauer, N. Mwanza, T. Maruhashi and T. Yumoto, "Conservation of Eastern Lowland Gorilla in the Kahuzi-Biega National Park, Zaire," University Louis Pasteur, Strasbourg, 1994, pp. 113122.

[22] A. J. Goodall, "Feeding and Ranging Behaviour of a Mountain Gorilla Group (Gorilla gorilla beringei) in the Tshibinda-Kahuzi Region (Zaire)," Primate Ecology Academic Press, London, 1977, pp. 450-479.

[23] D. F. Murnyak, "Censusing the Gorillas in Kahuzi-Biega National Park," Biological Conservation, Vol. 21, No. 3, 1981, pp. 163-176. doi:10.1016/0006-3207(81)90089-6
[24] H. L. Golterman, R. S. Clymo and M. A. N. Ohnstad, "Methods for Physical and Chemical Analysis of Freshwaters," Blackwell Scientific Publication, London, 1978, $213 \mathrm{p}$.

[25] APHA, "Standard Methods for the Examination of Water and Wastewater," American Public Health Association, 1989.

[26] R. G. Wetzel and G. E. Likens, "Limnological Analysis," Springer, Berlin, 2000, 429 p.

[27] M. A. L. Silva, C. F. Calasans, A. R. C. Ovalle and C. E. Rezende, "Dissloved Nitrogen and Phosphorus Dynamics in the Lower Portion of the Paraiba do Sulriver, Campos dos Goytacazes, RJ, Brazil," Brazilian Archives of Biology and Technology, Vol. 44, No. 4, 2001, pp. 385-371.

[28] K. Karume, "Biomass and Hydropower Potential and Demand in the Albertine Rift Region," Ph.D. Thesis, Makerere University, Uganda, 2006.

[29] P. A. Oluwande, M. K. C. Sridhar, A. O. Bammeke and A. O. Okubadejo, "Pollution Levels in Some Nigeria Rivers," Water Research, Vol. 17, No. 9, 1983, pp. 957-963. doi:10.1016/0043-1354(83)90035-0

[30] A. Vandelannoote, H. Deelstra, F. Vyumvuhore, L. Bitetera and F. Ollevier, "The Impact of the River Ntahangwa, the Most Polluted Burundian Tributary of Lake Tanganyika, on the Water Quality of the Lake," Hydrobiologia, 328, No. 2, 1996, pp. 175-187. doi:10.1007/BF00018713

[31] L. Bennasser, M. Fekhaoui, J. L. Benoit-Guyod and G. Merlin, "Influence de la Mare Sur la Qualité des Eaux du bas Sebou Soumis aux Rejets de la Plaine du Gharb (Maroc)," Water Resources, Vol. 31, 1997, pp. 859-867.

[32] R. E. Hecky, H. Bootsman and M. L. Kingdom, "Impact of Land Use on Sediment and Nutrient Yields in Lake Malawi/Nyassa (Africa)," Journal of Great Lakes Research, Vol. 29, Suppl. 2, 2003, pp. 139-156.

[33] T. P. Karthikeyani, T. P. Velavan and M. Ramesh, "Physico-Chemical and Biological Characterization of the River Shanmuganadhi, Tamil Nadu," Environment and Ecology, Vol. 20, No. 2, 2002, pp. 482-486.

[34] D. S. Fatoki, P. Gogwana and A. O. Ogunfowokan, "Pollution Assessment in the Keistamma River and It the Impoundment Downstream," Water SA, Vol. 29, No. 2, 2003, pp. 183-187.

[35] M. Meybeck and R. Helmer, "The Quality of Rivers: From Pristine Stage to Global Pollution," Paleogeography, Paleoclimatolgy, Palaeo Ecology, Vol. 75, No. 4, 1989, pp. 283-309.

[36] S. W. Nixon, "Remineralization and Nutrient Cycling in Coastal Marine Ecosystems," University of Rhode Island, Kingston, 1981, pp. 111-138.

[37] S. Dodson, "Introduction to Limnology," McGraw Hill, New York, 2005, 400 p.

[38] H. L. Golterman, "Physiological Limnology," Elsivier, New York, 1975, 489 p.

[39] B. Moss, "Ecology of Fresh Waters: Manand Medium," Blackwell Scientific Publications Ltd., Oxford, 1988, 417 p. 